\title{
IMPLEMENTASI KEBIJAKAN PROTOKOL KESEHATAN SERTA DAMPAKNYA TERHADAP EKONOMI MIKRO DI KABUPATEN NGAJUK
}

\author{
*Ajie Hanif Muzaqii', Muhammad Zainal Layfani' ${ }^{2)}$ \\ 1) Prodi Administrasi Publik Fakultas Ilmu Sosial dan Ilmu Politik Universitas Kadiri, Indonesia \\ 2) Prodi Administrasi Publik Fakultas Ilmu Sosial dan Ilmu Politik Universitas Kadiri, Indonesia \\ *Email Korespondensi : ajiehanif@unik-kediri.ac.id
}

\begin{abstract}
Abstrak
Kebijakan publik adalah cara dari pemerintah yang disepakati bersama untuk memenuhi tanggung jawab, seperti melindungi hak-hak dari masyarakat serta meningkatkan kesejahteraan warga Negara. Dunia pada sekarang ini sedang dilanda oleh wabah corona virus disease 2019 atau sering disebut Covid-19. Membuat berbagai sektor menjadi berantakan, tak terkecuali sektor ekonomi. Pemerintah Provinsi Jawa Timur kemudian membuat kebijakan Peraturan Gubernur Nomor 53 Tahun 2020 Tentang Penerapan Protokol Kesehatan dan Pengendalian Covid-19 untuk meminimalisisr peyebaran virus corona. Dimana peraturan tersebut wajib dipatuhi oleh seluruh masyarakat Jawa Timur. Adapun jenis penelitian ini adalah kualitatif yaitu metode yang berusaha menafsirkan dan memahami makna suatu peristiwa interaksi tingkah laku manusia dalam situasi tertentu menurut perspektif peneliti sendiri. Hasil penelitian menyebutkan bahwa kebijakan publik yang dikeluarkan Pemerintah Provinsi Jawa Timur melalui Peraturan Gubernur Nomor 53 Tahun 2020 banyak merugikan pelaku UMKM, karena penghasilan mereka menjadi berkurang akibat dari pembatasan jam operasional dan pembatasan pengunjung atau tidak diperbolehkan adanya kerumunan.
\end{abstract}

Kata Kunci: Kebijakan Publik; Covid-19; Peraturan Gubernur.

\begin{abstract}
Public policy is a mutually agreed way of government to fulfill responsibilities, such as protecting the rights of the community and improving the welfare of citizens. The world is currently being hit by an outbreak of the corona virus disease 2019 or often called Covid-19. Making various sectors into a mess, including the economic sector. The East Java Provincial Government then made a policy on Governor Regulation Number 53 of 2020 concerning the Implementation of the Health Protocol and Covid-19 Control to minimize the spread of the corona virus. Where these regulations must be obeyed by all the people of East Java. The type of this research is qualitative, namely a method that seeks to interpret and understand the meaning of an event of human behavior interaction in certain situations according to the researcher's own perspective. The
\end{abstract}


results of the study stated that the public policies issued by the East Java Provincial Government through Governor Regulation Number 53 of 2020 caused a lot of harm to MSME actors, because their income was reduced due to restrictions on operating hours and visitor restrictions or no crowds were allowed.

Keywords: Public policy; Covid-19; Governor Regulation.

\section{PENDAHULUAN}

Kebijakan publik adalah semua hal yang dibuat dan diputuskan oleh pemerintah. Ini menunjukkan bahwa pemerintah memiliki kewenangan untuk membuat kebijakan yang mempunyai sifat mengikat. Dalam proses pembuatannya, kebijakan publik idealnya melibatkan dialog antara masyarakat dengan pemerintah. Sehingga kebijakan tidak bersifat satu arah (Tyasotyaningarum \& Muzaqi, 2021). Kebijakan bersifat mengikat, sehingga aturan tersebut harus dipatuhi oleh siapapun tanpa terkecuali. Kebijakan publik harus memiliki keberpihakan kepada rakyat untuk menyelesaikan permasalahan yang berada di masyarakat.

Permasalahan yang mucul di masyarakat dewasa ini adalah lesunya perekonomian lokal akibat dari pandemi yang berkelanjutan. Perekonomian merupakan sektor yang sangat penting dan menjadi salah satu fokus pemerintah dalam berbagai kebijakan untuk mencapai kesejahteraan. Selain membutuhkan program dan kebijakan yang terarah, perekonomian juga membutuhkan modal atau pembangunan yang cukup besar. Modal menjadi masalah besar dalam dunia usaha karena menjadi pendukung peningkatan produktivitas dan taraf hidup masyarakat.

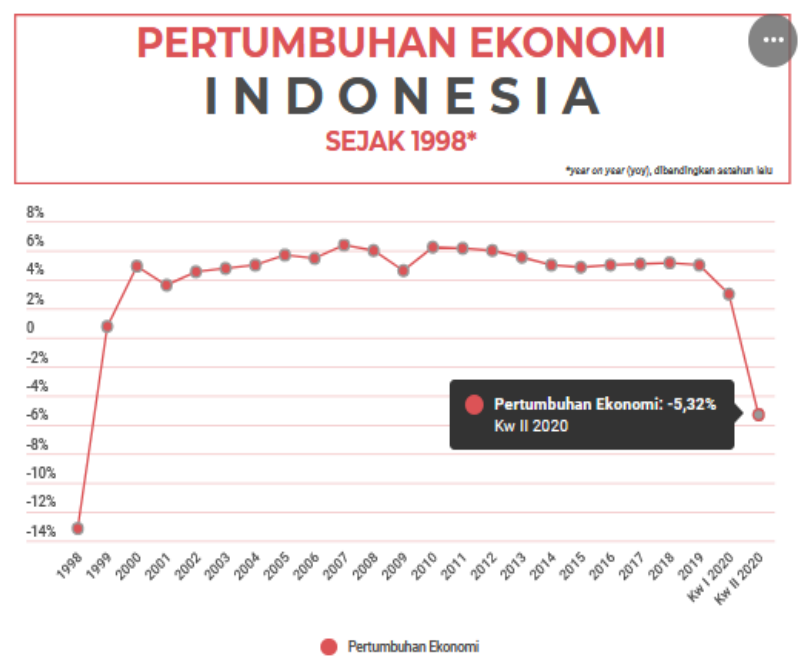

Copyright@2020; Jurnal Mediasosian - pISSN: 2579-342X, elSSN: 2620-5149| 187 


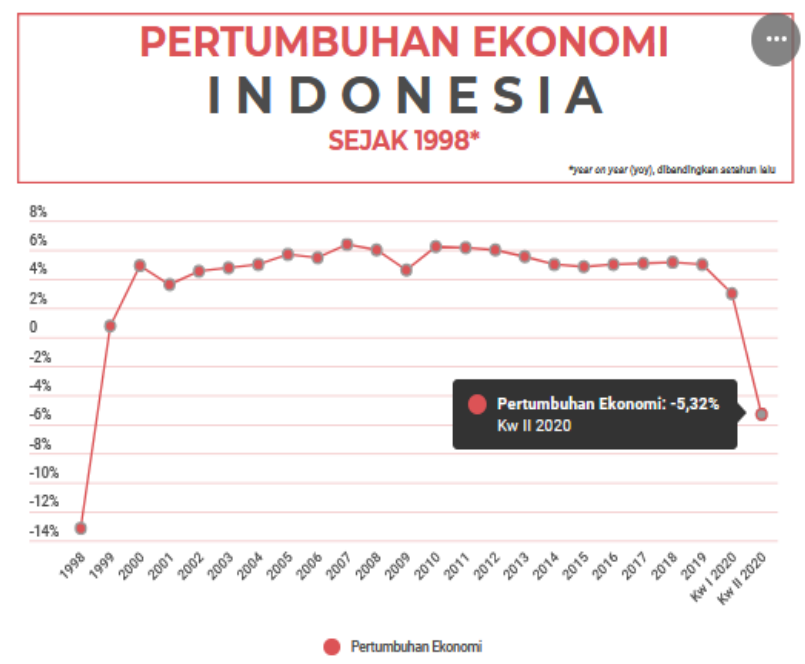

\section{Gambar 1 Pertumbuhan Ekonomi Indonesia Saat Pandemi}

Sumberr : (Indayani \& Hartono, 2020)

Pertumbuhan ekonomi pada masa sekarang ini juga dapat dicapai melalui peran dari usaha kecil dan menengah. Usaha kecil yaitu usaha yang memiliki aset maksimum Rp. 600.000.000 dan belum termasuk tanah atau rumah yang ditempati. Sedangkan usaha menengah adalah usaha yang memiliki total aset Rp. 50 milyar, belum termasuk tanah atau rumah yang ditempati dan beromset Rp. 250 milyar. Usaha kecil dan menengah dianggap menjadi pemegang peranan yang sangat penting dalam pembangunan ekonomi lokal, karena usaha ini mampu menciptakan lapangan pekerjaan dan ikut andil dalam mensejahterakan masyarakat (Mirza, 2012) Oleh karena itu usaha kecil dan menengah juga merupakan tulang punggung pembangunan ekonomi.

Pandemi menyebabkan perekonomian lokal menjadi terhambat. Pemerintah dihadapkan pada pilihan menyelamatkan perekonomian atau kesehatan rakyat. Melalui Instruksi Presiden Republik Indonesia (Inpres) Nomor 6 Tahun 2020 Tentang Peningkatan Disiplin dan Penegakan Hukum Protokol Kesehatan dalam Pencegahan dan Pengendalian Corona Virus Disease 2019, diharapkan dapat menjadi solusi dari permasalahan urgent yang saat ini sedang dihadapi. Selain itu Inpres Nomor 6 Tahun 2020 ini juga menginstruksikan para Kepala Pemerintahan seperti Gubernur, Bupati dan 
Walikota untuk melakukan perlindungan kesehatan kepada masyarakat untuk mencegah penularan virus corona.

Turunan dari Inpres ini adalah Peraturan Gubernur (PERGUB) Jawa Timur Nomor 53 Tahun 2020 Tentang Penerapan Protokol Kesehatan dan Pengendalian Corona Virus Disease 2019. Peraturan Gubernur tersebut digunakan dalam upaya penanganan dan pencegahan untuk memutus rantai penularan Covid-19 yang pelaksanaanya dilakukan secara menyeluruh dari berbagai aspek penyelenggaraan pemerintah, kesehatan, sosial budaya , dan ekonomi. Peraturan Gubernur juga tersebut menghimbau kepada masyarakat untuk selalu mematuhi protokol kesehatan.

Demi kelancaran dari Peraturan Gubernur tersebut, keikutsertaan masyarakat sangat penting. Kebijakan yang sukses adalah kebijakan yang dimana masyarakat sebagai pelaksana dari kebijakan mau bekerja sama untuk menyelesaikan masalah bersama dengan pemerintah. Dengan ini partisipasi masyarakat diperlukan. Partisipasi adalah kemauan atau keinginikutsertaan dari seseorang untuk melakukan sesuatu tanpa paksaan (Duadji, 2013). Partisipasi masyarakat sangat menentukan keberhasilan suatu perencanaan atau program-program yang dibuat oleh pemerintah. Oleh karena itu, partisipasi menjadi tolak ukur apakah kebijakan tersebut berhasil atau tidak.

Di Kabupaten Nganjuk sendiri, kasus Covid-19 cenderung meningkat, dimana di awal tahun 2021 Kabupaten Nganjuk menjadi daerah dengan kasus positif terbanyak di Jawa Timur. Setidaknya 230 kasus baru tercatat di Kabupaten Nganjuk, mengakibatkan penambahan kasus baru di Jawa Timur sebanyak 1198 kasus baru. Menjadikan Kabupaten Nganjuk mendapatkan perhatian lebih dalam penanganan kasus virus corona. Bupati Nganjuk kemudian menerapkan jam malam agar masyarakat tidak berkerumun dan keluar rumah pada waktu-waktu tertentu untuk mengurangi penambahan kasus baru di Kabupaten Nganjuk. 


\begin{tabular}{|c|c|c|c|c|c|c|}
\hline KECAMATAN & $\begin{array}{c}\text { PROPAB } \\
\text { LE }\end{array}$ & SUSPECT & $\begin{array}{c}\text { KONTAK } \\
\text { ERAT }\end{array}$ & $\begin{array}{c}\text { KONFIRM } \\
\text { ASI }\end{array}$ & SEMBUH & $\begin{array}{c}\text { MENING } \\
\text { GAL }\end{array}$ \\
\hline IBAGOR & 2 & 53 & 326 & 45 & 37 & 3 \\
\hline 2BARON & - & 36 & 181 & 48 & 40 & 6 \\
\hline 3BERBEK & 4 & 34 & 311 & 58 & 46 & 9 \\
\hline 4GONDANG & 2 & 29 & 317 & 26 & 20 & 4 \\
\hline 5JATIKALEN & 1 & 5 & 1 & 5 & 5 & - \\
\hline GKERTOSONO & - & 47 & 338 & 133 & 94 & 21 \\
\hline 7LENGKONG & 1 & 15 & 80 & 10 & 6 & 4 \\
\hline 8LOCERET & 1 & 74 & 334 & 91 & 74 & 7 \\
\hline 9NGANJUK & 4 & 85 & 785 & 93 & 69 & 7 \\
\hline 1ONGETOS & 2 & 14 & 84 & 18 & 15 & - \\
\hline 11 NGLUYU & - & 8 & 34 & 3 & 2 & - \\
\hline 12NGRONGGOT & - & 41 & 435 & 74 & 60 & 6 \\
\hline 13PACE & 1 & 47 & 653 & 57 & 50 & 3 \\
\hline 14PATIANROWO & - & 25 & 155 & 35 & 28 & 4 \\
\hline 15PRAMBON & - & 29 & 134 & 48 & 32 & 5 \\
\hline 16REJOSO & - & 48 & 226 & 29 & 26 & 2 \\
\hline 17SAWAHAN & - & 16 & 190 & 24 & 18 & 2 \\
\hline I8SUKOMORO & - & 39 & 53 & 23 & 16 & 5 \\
\hline 19TANJUNGANOM & - & 81 & 567 & 74 & 62 & 5 \\
\hline 20WILANGAN & - & 18 & 351 & 15 & 15 & - \\
\hline KABUPATEN NGANJUK & 18 & 744 & 5,555 & 909 & 715 & 92 \\
\hline
\end{tabular}

\section{Gambar 2. Pertumbuhan Ekonomi Indonesia Saat Pandemi}

Sumber: Pusat Informasi Pemkab Nganjuk

Berdasarkan hal di atas peneliti tertarik untuk menganalisis implementasi kebijakan Peraturan Gubernur Nomor 53 tahun 2020 pasal 3 yang berdampak langsung terhadap penekanan kasus terinfeksi Covid-19 pada sektor perekonomian lokal. Pada penelitian ini, peneliti memilih pelaku UMKM Kabupaten Nganjuk untuk menjadikan target dalam mencari informasi tentang stabilitas ekonomi pada masa pandemi Covid-19. Sebab UMKM merupakan penggerak roda perekonomian yang penting dalam kehidupan ekonomi masyarakat terutama masyarakat Kabupaten Nganjuk. Dilain sisi, pandemi Covid-19 juga mengganggu dari jalannya stabilitas ekonomi tersebut.

\section{TINJAUAN PUSTAKA}

\section{a. Kebijakan Publik}

Kebijakan publik adalah suatu cara dari pemerintah yang telah disepakati bersama untuk memenuhi tanggung jawab, seperti melindungi hak-hak dari masyarakat serta meningkatkan kesejahteraan warga Negara (Akbar et al., 2018). Menurut Irfan Islamy, kebijakan publik merupakan rangkaian kegiatan yang telah ditentukan dan dilakukan atau tidak dilakukan oleh pemerintah yang memiliki sebuah tujuan tertentu demi kepentingan seluruh masyarakat. Sedangkan menurut (Dye, 2013), kebijakan publik adalah kebijakan- 
kebijakan yang dikembangkan oleh lembaga-lembaga pemerintahan (Grindle, 2017). Akan tetapi, kebijakan publik tidak dapat dibuat oleh sembarang orang atau sembarang lembaga. Kebijakan publik hanya dapat dibuat oleh seseorang atau lembaga yang dalam udang-undang berhak dan berwenang membuat suatu kebijakan publik untuk kepentingan masyarakat. Karena kebijakan publik harus memiliki tujuan yaitu pemecahan masalah publik, proses memecahkan suatu permasalahan publik seperti yang diutarakan oleh (Dunn, 2015) adalah, (1) penetapan agenda kebijakan, (2) adopsi kebijakan, (3) implementasi kebijakan, (4) evaluasi kebijakan.

Proses kebijakan publik adalah serangkaian proses intelektual yang dilakukan dan bersifat politis (Ramdhani \& Ramdhani, 2017) Kegiatan politis yang dimaksud merupakan proses yang disebutkan sebelumnya, mulai dari penyusunan agenda, formulasi kebijakan, adopsi kebijakan, implementasi kebijakan, dan evaluasi kebijakan. Sedangkan proses perumusan kebijakan seperti analisis kebijakan, pengesahan kebijakan, implementasi kebijakan, dan evaluasi kebijakan. Perumusan kebijakan publik merupakan pokok dari kebijakan publik itu sendiri, karena berisi batas-batas dari kebijakan.

Dari penjelasan diatas, maka dari itu kebijakan publik adalah suatu ketetapan dari lembaga pemerintahan yang dikeluarkan untuk mengatasi suatu permasalahan publik dan tentunya untuk kepentingan seluruh masyarkat serta dapat dikembangkan kembali di masa yang akan datang sesuai hasil dari implementasi dan evaluasi kebijakan itu sendiri.

\section{b. Implementasi Kebijakan Publik}

Secara teoritis, teori tentang implementasi kebijakan seperti yang dikemukakan oleh (EDWARD III, 1980) sebagaimana dideskripsikan oleh Subarsono, berpandangan bahwa implementasi kebijakan dipengaruhi oleh empat variabel, yaitu:

a) Komunikasi.

Keberhasilan implementasi kebijakan mensyaratkan agar implementor mengetahui apa yang harus dilakukan, dimana yang menjadi tujuan dan sasaran kebijakan harus ditransmisikan kepada kelompok sasaran (target group), sehingga akan mengurangi distorsi implementasi. Menurut pandangan Edward III sebagaimana dikutip oleh Budi Winarno, proses komunikasi 
kebijakan dipengaruhi tiga hal penting, yaitu: a) Faktor pertama yang berpengaruh terhadap komunikasi kebijakan adalah transmisi. Sebelum pejabat dapat mengimplementasikan suatu keputusan, harus menyadari bahwa suatu keputusan telah dibuat dan suatu perintah untuk pelaksanaannya telah dikeluarkan; b) Faktor kedua adalah kejelasan. Jika kebijakan-kebijakan di implementasikan sebagaimana yang diinginkan, maka petunjuk-petunjuk pelaksanaan tidak hanya harus diterima oleh para pelaksana kebijakan, tetapi juga komunikasi kebijakan tersebut harus jelas. Seringkali instruksi-intruksi yang diteruskan kepada pelaksana tidak jelas dan tidak menetapkan kapan dan bagaimana suatu program dilaksanakan; dan c) Faktor ketiga adalah konsistensi. Jika implementasi kebijakan ingin berlangsung efektif, maka perintah-perintah pelaksaan harus konsisten dan jelas. Walaupun perintahperintah yang disampaikan kepada pelaksana kebijakan jelas, tetapi bila perintah tersebut bertentangan maka perintah tersebut tidak akan memudahkan para pelaksana kebijakan menjalankan tugasnya dengan baik.

b). Sumberdaya.

Meskipun isi kebijakan telah dikomunikasikan secara jelas dan konsisten, tetapi apabila implementor kekurangan sumberdaya manusia untuk melaksanakan, maka implementasi tidak akan berjalan efektif. Sumber daya tersebut dapat berwujud sumber daya manusia, misalnya kompetensi implementor dan sumber daya finansial.

c). Disposisi.

Disposisi adalah watak dan karakteristik sumber daya manusia yang dimiliki oleh implementor, seperti komitmen, kejujuran, sifat demokratis. Apabila implementor memiliki disposisi yang baik, maka implementor tersebut dapat menjalankan kebijakan dengan baik seperti apa yang diinginkan oleh pembuat kebijakan. Ketika implementor memiliki sikap atau perspektif yang berbeda dengan pembuat kebijakan, maka proses implementasi kebijakan juga menjadi tidak efektif.

d). Struktur Birokrasi. 
Struktur organisasi yang bertugas mengimplementasikan kebijakan memiliki pengaruh yang signifikan terhadap implementasi kebijakan. Aspek dari struktur organisasi adalah Standard Operating Procedure (SOP) dan fragmentasi. Struktur organisasi yang terlalu panjang akan cenderung melemahkan pengawasan dan menimbulkan red-tape, yakni prosedur birokrasi yang rumit dan kompleks, yang menjadikan aktivitas organisasi tidak fleksibel. (Subarsono, 2011)

Jadi, implementasi kebijakan publik adalah suatu kegiatan yang dilakukan oleh organisasi publik dan bertujuan untuk mencapai tujuan tertentu yang telah ditetapkan pada keputusan kebijakan publik. Implementasi kebijakan publik tidak akan dapat dilaksanakan tanpa adanya tujuan dan sasaran yang belum ditetapkan. Dan implementasi kebijakan publik tidak dapat terlaksana tanpa adanya partisipasi dari masyarakat.

\section{METODE PENELITIAN}

Jenis penelitian yang digunakan adalah jenis penelitian kualitatif yaitu dengan menjelaskan dan menguraikan secara sistematis mengenai permasalahan yang akan diteliti melalui proses analisis yang dilakukan dengan mengumpulkan data - data, kemudian di analisa sehingga memberikan gambaran yang jelas mengenai objek yang diteliti, kemudian ditarik kesimpulan. Penelitian kualitatif adalah penelitian yang bermaksud untuk memahami fenomena tentang apa yang dialami oleh subyek penelitian misalnya perilaku, persepsi, motivasi, tindakan, dll. Penelitian kualitatif termasuk dalam penelitian lapangan, yaitu dimana penelitian dilakukan langsung di lapangan atau kepada narasumber (Sugiyono, 2016).

Adapun lokasi penelitian yang dipilih adalah Kabupaten Nganjuk. Pertimbangannya berdasarkan observasi yang dilakukan peneliti meliputi:

1. Dinas Tenaga Kerja Koperasi dan Usaha Mikro Daerah Kabupaten Nganjuk.

2. Badan Penanggulangan Bencana Daerah Kabupaten Nganjuk.

3. Satuan Polisi Pamong Praja Kabupaten Nganjuk.

4. UMKM Desa Lengkong, Kabupaten Nganjuk. 
Sementara itu, Untuk mengumpulkan data yang diperlukan dalam penelitian ini, maka penulis menggunakan analisis data versi (Miles \& Huberman, 1994), bahwa ada tiga alur kegiatan, yaitu reduksi data, penyajian data, serta penarikan kesimpulan atau verifikasi:

1. Reduksi data diartikan sebagai proses pemilihan, pemusatan perhatian pada penyederhanaan, pengabstrakan, dan transformasi data "kasar" yang muncul dari catatan lapangan. Reduksi dilakukan sejak pengumpulan data, dimulai dengan membuat ringkasan, mengkode, menelusuri tema, menulis memo, dan lain sebagainya, dengan maksud menyisihkan data atau informasi yang tidak relevan, kemudian data tersebut diverifikasi.

2. Penyajian data adalah pendeskripsian sekumpulan informasi tersusun yang memberikan kemungkinan adanya penarikan kesimpulan dan pengambilan tindakan. Penyajian data kualitatif disajikan dalam bentuk teks naratif, dengan tujuan dirancang guna menggabungkan informasi yang tersusun dalam bentuk yang padu dan mudah dipahami.

3. Penarikan kesimpulan atau verifikasi merupakan kegiatan akhir penelitian kualitatif. Peneliti harus sampai pada kesimpulan dan melakukan verifikasi, baik dari segi makna maupun kebenaran kesimpulan yang disepakati oleh tempat penelitian itu dilaksanakan. Makna yang dirumuskan peneliti dari data harus diuji kebenaran, kecocokan, dan kekokohannya. Peneliti harus menyadari bahwa dalam mencari makna, ia harus menggunakan pendekatan emik, yaitu dari kacamata key information, dan bukan penafsiran makna menurut pandangan peneliti (pandangan etik). 


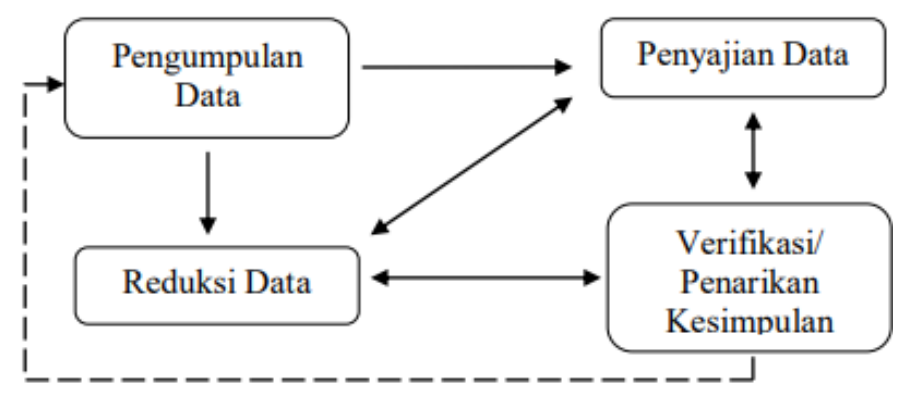

Gambar 3. Analisis Data Interaktif

Sumber : (Miles \& Huberman, 1994)

\section{HASIL DAN PEMBAHASAN}

\section{a. Dimensi Komunikasi dalam konteks Implementasi Peraturan Gubernur Nomor 53 Tahun 2020 di Kabupaten Nganjuk}

Komunikasi yang dilakukan oleh stakeholders sudah cukup baik. Karena dapat diterima dan dilaksanakan oleh pelaksana kebijakan sesuai dengan teori dari (EDWARD III, 1980). Komunikasi yang dijalankan dengan cara langsung maupun tidak langsung juga dapat dipahami dan dilaksanakan dengan baik. Integrasi antara para pihak berwajib mampu dengan efektif mensosialisasikan kebijakan sesuai dengan dimensi transimisi dan menyampaikan kepada masyarakat umum dalam hal ini menurut kebijakan sasarannya adalah para pelaku UMKM. Meskipun tidak jarang ada pro dan kontra karena kebijakan ini karena kebijakan ini mempengaruhi perekonomian mereka. Namun pada akhirnya tetap dapat di implementasikan dengan baik demi kepentingan bersama untuk menekan penyebaran Covid-19.

Komunikasi yang dilakukan secara langsung dengan melakukan sosialisasi dengan cara mendatangi lokasi dimana pelaksana kebijakan berada. Tentunya dengan pendekatan yang baik sehingga dapat diterima dengan baik oleh mereka. Selain secara langsung, komunikasi juga dilakukan secara tidak langsung, menggunakan perantara banner atau brosur selebaran yang diberikan kepada masyarakat umum. Banner diletakkan 
pada lokasi-lokasi strategis yang sekiranya dapat dilihat dan dibaca oleh banyak orang. Dengan hal-hal tersebut, maka implementasi kebijakan dapat cepat terlaksana dengan baik.

\section{b. Dimensi Struktur Birokrasi dalam konteks Implementasi Peraturan}

\section{Gubernur Nomor 53 Tahun 2020 di Kabupaten Nganjuk}

Pada Dinas Tenaga Kerja Koperasi dan Usaha Mikro Daerah Kabupaten Nganjuk, struktur birokrasi berjalan dengan baik. Terdapat pembagian kerja sesuai dengan job descriptionnya masing-masing. Dan mereka bertanggung jawab atas pekerjaan yang mereka lakukan. Sistem monitoring juga dilakukan untuk mencegah adanya penyalahgunaan jabatan yang diberikan. Struktur birokrasi merupakan unsur yang penting dan berpengaruh terhadap efektivitas implementasi. Ketika struktur birokrasi tidak kondusif terhadap implementasi suatu kebijakan, maka hal ini akan menyebabkan ketidakefektivan dan menghambat jalannya pelaksanaan kebijakan. Dengan adanya struktur birokrasi yang baik, maka implementasi kebijakan juga akan berjalan dengan baik pula.

c. Dimensi Sumber Daya dalam konteks Implementasi Peraturan Gubernur Nomor 53 Tahun 2020 di Kabupaten Nganjuk

Menurut Edward III mengatakan bahwa faktor sumber daya mempunyai peranan penting dalam implementasi kebijakan. Sumber daya menjadi penting sebab tanpa adanya sumber daya yang menunjang suatu birokrasi, maka implementasi kebijakan tidak dapat berjalan dengan baik. Implementasi kebijakan menjadi tidak efektif meskipun perintahperintah implementasi diteruskan secara cermat, jelas dan konsisten, apabila memiliki kekurangan sumber-sumber yang diperlukan oleh pelaksana untuk menjalankan kebijakan. Hasil penelitian menunjukan bahwa Dinas Tenaga Kerja Koperasi dan Usaha Mikro Kabupaten Nganjuk memiliki sumber daya yang cukup baik untuk menunjang keberhasilan implementasi kebijakan. Sumber daya manusia yang kompeten dan dukungan sarana prasarana yang cukup lengkap diharapkan mampu mempengaruhi keberhasilan implementasi kebijakan. Dukungan sumber daya juga tidak hanya pada Dinas Tenaga Kerja Koperasi dan Usaha Mikro Kabupaten Nganjuk saja, melainkan harus 
ada di seluruh birokrasi di manapun. Dengan adanya sumber daya segala bentuk implementasi kebijakan bukan tidak mungkin dapat dilaksanakan dengan baik.

\section{d. Dimensi Disposisi dalam konteks Implementasi Peraturan Gubernur Nomor}

\section{Tahun 2020 di Kabupaten Nganjuk}

Pelaku UMKM sebagai pelaksana kebijakan merasa kurang diuntungkan dengan peraturan pembatasan-pembatasan yang diterapkan. Jam operasional yang biasanya sampai larut malam hanya harus tutup pukul 08.00 kurang, tentunya merugikan pelaku UMKM. Pembatasan pengunjung juga menyebabkan pendapatan menurun. Intensif yang diberikan dari pemerintah kepada pelaku UMKM dirasa salah sasaran, meskipun sudah menyertakan berkas-berkas yang perlu dikumpulkan. Selain ingin pandemi Covid-19 cepat usai, pelaksana kebijakan menginginkan kebijakan yang juga dapat menguntungkan mereka. Kebijakan yang tidak harus mempengaruhi penghasilan namun juga tetap terbebas dari paparan Covid-19.

Sesuai dengan teori Edward III tentang disposisi, pelaku UMKM sebagai pelaksana kebijakan mau dan melaksanakan kebijakan pembatasan dan protokol kesehatan, karena mereka berkeinginan untuk hidup normal seperti sebelum adanya pandemi dan mendapatkan penghasilan seperti dulu lagi. Namun selain itu ada keinginan untuk digantikannya kebijakan dengan kebijakan yang lebih menguntungkan mereka, sehingga tidak hanya bebas dari virus namun pendapatan usaha tetap stabil.

\section{e. Kondisi PDRB Kabupaten Nganjuk}

Dibandingkan tahun 2019, sebelum adanya Covid-19, ekonomi pada tahun 2020 secara umum mengalami kontraksi, baik pada level Nasional, Provinsi sampai Daerah Kabupaten atau Kota akibat dari terdampak Covid-19. Ekonomi Kabupaten Nganjuk pada tahun 2020 terkontraksi bila dibandingkan tahun 2019 yaitu sebesar 1,71 persen. Hampir semua komponen PDRB Menurut Pengeluaran mengalami kontraksi. Pandemi Covid-19 menyebabkan perekonomian menjadi lesu. Dengan adanya Covid-19 juga menyebabkan masyarakat menjadi takut untuk keluar rumah, hal tersebut mengakibatkan para pelaku UMKM baik yang bertempat di lokasi pariwisata maupun bukan tidak mendapatkan pemasukan. Sehingga hal tersebut menjadikan perekonomian daerah menjadi menurun. 


\section{f. Kondisi Sektor Ekonomi Mikro}

Pada masa pandemi Covid-19, perekonomian mikro sedang digempur oleh berbagai macam kendala dan masalahnya. Masyarakat yang enggan keluar rumah menjadikan bisnis UMKM menjadi terhambat. Padahal UMKM adalah salah satu penggerak peekonomian dimana didalamnya terdapat orang-orang yang menggantungkan hidup padanya. Dalam indikator pertumbuhan ekonomi daerah, terdapat ketidakseimbangan pendapatan menjadi faktor yang penting. Di masa sulit seperti saat ini, pendapatan pelaku UMKM jelas menurun. Ditambah lagi dengan kebijakan-kebijakan pembatasan sosial yang diberlakukan. Pembatasan sosial menyebabkan interaksi jual beli konsumen dan penjual menjadi terganggu. Dibandingkan dengan sebelum adanya Covid19, pendapatan atau pengahasilan pelaku UMKM sangat berbeda. Pelaksana kebijakan dalam hal ini pelaku UMKM berharap pandemi segera usai dan perekonomian mereka kembali seperti dulu lagi.

\section{g. Ketersediaan Lapangan Pekerjaan}

Menurut Badan Pusat Statistik, lapangan pekerjaan adalah bidang kegiatan dari usaha/ perusahaan/ instansi dimana seseorang bekerja atau pernah bekerja. Lapangan usaha adalah bidang kegiatan dari pekerjaan/ usaha/ perusahaan/ kantor/ tempat seseorang bekerja. Lapangan pekerjaan dibagi menjadi beberapa golongan yaitu sektor pertanian, sekotr industri pengolahan, sektor perdagangan, sektor jasa, sektor angkutan, dan sektorsektor lainnya. Dari masing masing sektor tersebut akan menyerap tenaga kerja. Lapangan kerja juga digunakan sebagai peluang usaha bagi mereka yang kreatif. Penciptaan lapangan kerja yang luas akan menambah pendapatan bagi penduduk yang bersangkutan.

Akibat dari adanya pandemi Covid-19, banyak perusahaan atau usaha mikro harus merumahkan pegawainya. Karena terjadi ketidakseimbangan pendapatan. Hal tersebut mengakibatkan banyaknya pengangguran yang ingin mendapatkan pekerjaan. Meskipun angka pengangguran meningkat, tidak diimbangi dengan jumlah lowongan pekerjaan yang tersedia. Sebab perusahaan atau usaha mikro juga harus berpikir dua kali untuk memperkerjakan pegawai, dimana pendapatan untuk biaya operasional sudah tidak maksimal ditambah harus menggaji pegawai. Solusinya adalah bagi mereka yang tidak kunjung mendapatkan pekerjaan dapat menciptakan lapangan pekerjaan itu sendiri 
dengan cara mulai berwirausaha, sehingga tidak perlu menunggu ketersediaan lapangan pekerjaan.

\section{KESIMPULAN}

Berdasarkan hasil penelitian sebagaimana dijelaskan pada bab terdahulu, maka dapat ditarik kesimpulan sebagai berikut:

1. Implementasi Peraturan Gubernur Nomor 53 tahun 2020 tentang penerapan protokol kesehatan dapat dilaksanakan dengan baik sebab:

a. Komunikasi telah terjalin antara pembuat kebijakan, kemudian kepada lembaga terkait dan di teruskan kepada masyarakat (Pelaku UMKM) dan dapat diterima dan dilaksanakan dengan baik.

b. Struktur birokrasi pada Dinas Tenaga Kerja Koperasi dan Usaha Mikro Daerah Kabupaten Nganjuk cukup baik, dengan adanya pembagian tugas yang terintegrasi satu dengan yang lain. Menjadikan implementasi kebijakan dapat terwujud.

c. Sumber daya pada Dinas Tenaga Kerja Koperasi dan Usaha Mikro Daerah Kabupaten Nganjuk cukup baik, sebab tenaga kerja atau sumber daya mausia yang kompeten dan ditunjang dengan sarana dan prasarana yang baik pula. Sehingga implementasi kebijakan dapat dilaksanakan.

d. Pelaku UMKM merasa bahwa kebijakan pembatasan sosial merugikan mereka dari segi penghasilan. Dan juga intensif dari pemerintah seringkali salah sasaran.

2. Faktor yang mendukung atau menghambat perekonomian akibat dari implementasi Peraturan Gubernur Nomor 53 tahun 2020 tentang penerapan protokol kesehatan dalam pencegahan dan pengendalian Covid-19.

a. Kondisi PDRB Kabupaten Nganjuk pada tahun 2020 atau pada saat masa pandemi mengalami kontraksi dibanding dengan tahun sebelumnya. Merupakan dampak dari lesunya perekonomian setahun belakangan ini.

b. Perekonomian mikro mengalami penurunan pendapatan sebagai dampak dari adanya pembatasan-pembatasan sosial di masa pandemi Covid-19. Mengakibatkan pelaku UMKM merasa dirugikan. 
c. Lapangan pekerjaan sulit di masa pandemi, sebab perusahaan juga harus membiayai operasional mereka sendiri, belum lagi harus menggaji pegawai. Sehingga angka pencari kerja juga cukup tinggi.

\section{REFERENSI}

Akbar, M. F., Suprapto, S., \& Surati, S. (2018). Partisipasi Masyarakat Dalam Perencanaan Pembangunan di Desa Jatimulya Kabupaten Boalemo. Publik : (Jurnal Ilmu Administrasi), 6(2), 135. https://doi.org/10.31314/pjia.6.2.135-142.2017

Duadji, N. (2013). Partisipasi publik dalam pengambilan keputusan anggaran pendapatan dan belanja daerah (APBD) Provinsi Lampung. Jurnal Bina Praja: Journal of Home Affairs Governance, 5(3), 197-203.

Dunn, W. N. (2015). Public policy analysis. Routledge.

Dye, T. R. (2013). Understanding public policy: Pearson new international edition. Pearson Higher Ed.

EDWARD III, G. C. (1980). Implementing public policy. Congressional Quarterly Press.

Grindle, M. S. (2017). Politics and policy implementation in the Third World (Vol. 4880). Princeton University Press.

Indayani, S., \& Hartono, B. (2020). Analisis Pengangguran Dan Pertumbuhan Ekonomi Sebagai Akibat Pandemi Covid-19. Jurnal Perspektif, 18(2), 201-208.

Miles, M. B., \& Huberman, A. M. (1994). Qualitative data analysis: An expanded sourcebook. sage.

Mirza, D. S. (2012). Pengaruh kemiskinan, pertumbuhan ekonomi, dan belanja modal terhadap indeks pembangunan manusia di Jawa Tengah tahun 2006-2009. Economics Development Analysis Journal, 1(2).

Ramdhani, A., \& Ramdhani, M. A. (2017). Konsep umum pelaksanaan kebijakan publik. Jurnal Publik, 11(1), 1-12.

Sugiyono. (2016). Metode Penelitian Kuantitatif, Kualitatif dan R\&B. PT. Alfabet.

Tyasotyaningarum, B., \& Muzaqi, A. H. (2021). PRAKTIK PELAYANAN PUBLIK DI DAERAH: OPTIMALISASI PENYELENGGARAAN PELAYANAN PUBLIK BERDASARKAN KINERJA ORGANISASI PERANGKAT DAERAH DI KABUPATEN NGANJUK. Jurnal Mediasosian: Jurnal Ilmu Sosial Dan Administrasi Negara, 5(1), 115-131. 